\title{
Bioactive composites for bone regeneration
}

\begin{abstract}
Alexandra-Cristina Burdușel 1,*
1 Department of Science and Engineering of Oxide Materials and Nanomaterials, Faculty of Applied Chemistry and Materials Science, University Politehnica of Bucharest, 1-7 Gheorghe Polizu Street, 011061 Bucharest, Romania

* Correspondence: alexandra burdu@yahoo.com.sg; Scopus ID: 57202255777

Abstract: Bone, the organ that separates vertebrates from other living beings, is a complex tissue responsible of mobility, body stability, organ protection, and metabolic activities such as ion storage. Ceramic materials are appropriate candidates to be used in the fabrication of scaffolds for bone healing. Biocompatible ceramic materials may also be created to deliver biologically active substances aimed at maintaining, repairing, restoring, or boosting the function of tissues and organs in the organism. Glass-ceramic materials furnish flexible properties appropriate for some particular applications. Because of the controlled devitrification and the evolution of variable dimensions of crystalline and glassy phases, glass-ceramics considerably overcome the lacunae found in glasses. A wide range of bioactive glass compositions had been developed since the early 1970s to make them appropriate for many clinical applications. Many bioactive ceramic composite materials attach to living bone through an apatite layer, which is developed on their surfaces in the living body. This paper reviews the most used bioactive ceramics for bone tissue regeneration, with specific accentuation on the material characteristics.
\end{abstract}

Keywords: bioactive, ceramics, bioglass, polymers.

(C) 2019 by the authors. Submitted for possible open access publication under the terms and conditions of the Creative Commons Attribution (CC BY) license (http://creativecommons.org/licenses/by/4.0/).

\section{Introduction}

The second most commonly transplanted tissue worldwide is the bone, having over four million operations using bone substitutes or bone graft materials annually to heal bone defects [1]. In thinking about the determinants of bone strength and how bone strength changes with age, one must consider several important concepts. To begin with, in contrast to most engineering materials, the bone is consistently adapting to modifications in its mechanical and hormonal environment and has the ability of repair and self-renewal. A second vital concept concerns the hierarchical nature of the parameters that influence whole-bone strength. Changes at the cellular, matrix, microarchitectural, and macroarchitectural levels may all affect the

bone mechanical properties, though not all to the same degree [2].

Injury, trauma, and disease can prompt degeneration and damage of tissues in the human body, which need treatments to promote their replacement, repair, or regeneration. Treatment usually concentrates on transplanting tissue from one site to another in the same patient (an autograft) or from one individual to another (a transplant or allograft). Alternatively, the domain of tissue engineering (a phrase that is correspondently used with regenerative medicine) intends to regenerate affected tissues, instead of replacing them, by designing biological substitutes that maintain, restore, or improve tissue activity[3].

BIOMEDICAL ENGINEERING INTERNATIONAL | https://biomedicalengineering.international | 9

Cite This Article: Burdușel, A.C. Bioactive composites for bone regeneration. Biomed Eng Int 2019, 1, 0009-0015. https://doi.org/10.33263/BioMed11.009015 
Bioceramics are an extended class of advanced designed semicrystalline, amorphous, or crystalline materials used for reconstruction and repair of damaged or diseased pieces of the body. Calcium sulfate (also known as "plaster of Paris") was firstly implanted as a bone void filler in living humans affected by tuberculous osteomyelitis in 1892 [4]. Taking into account the reactivity of bioceramics found inside the living body, basic responses have permitted them to be classified as almost bioinert, resorbable, and bioactive. Bioactive ceramics are those where a sequence of reactions, restricted only to the material surface, occurs yielding a mechanically strong bond between the living tissues and the bioceramic. Almost bioinert ceramics are considered as first-generation bioceramics, whereas bioactive and resorbable ceramics are known as second-generation bioceramics [5].

Notwithstanding the development of numerous biomaterials, such as calcium phosphate cements (CPC), metal implants, hydroxyapatite, etc., the wished therapeutic effect is not fully accomplished. Presently, polymeric scaffolds, especially hydrogels, are of interest and their rare configurations and tunable physicochemical properties have been extensively studied. Many studies concerning inorganic materials used in bone repair have appeared. Ceramics are a kind of inorganic material that proved excellent mechanical properties and osteo-conduciveness and have been favorably used in alveolar bone repair. In the past decades, polymer scaffolds have been extensively analyzed in bone tissue engineering [6]. Bone nonunion has turned out to be one of the most serious sequelae of infections, fractures, bone tumors, or revision arthroplasty owing to its high morbidity and disability rate. Recently, bone nonunion has gotten significant consideration from plastic surgeons. There are various types of materials for the manufacturing of bioactive scaffolds, from the application of long-established metal materials like titanium, to the recently designed hydrogels. All materials show unique osteogenic ability. Table 1 mainly presents the advantages and potential limitations of the numerous materials used in the treatment of bone nonunion [7].

Table 1. Advantages and potential limitations of various materials used in treatment of bone nonunion [7]. Reprinted from an open access source.

\begin{tabular}{|c|c|c|c|}
\hline Materials & $\begin{array}{l}\text { Detailed } \\
\text { classification }\end{array}$ & Advantages & Potential limitations \\
\hline \multirow{2}{*}{ Metals } & Inert metal & $\begin{array}{l}\text { Great biocompatibility } \\
\text { Excellent mechanical strength } \\
\text { Excellent mechanical properties may } \\
\text { be beneficial in the case of slow } \\
\text { bone growth }\end{array}$ & $\begin{array}{l}\text { Released metal ions cause a toxic } \\
\text { reaction } \\
\text { Stress shielding further leads to } \\
\text { osteolysis } \\
\text { Completely unable to degrade }\end{array}$ \\
\hline & Degradable metal & $\begin{array}{l}\text { Sufficient stability } \\
\text { Moderate and uniform degradation } \\
\text { Excellent biocompatibility and } \\
\text { osteoinductivity } \\
\text { Promotes angiogenesis }\end{array}$ & $\begin{array}{l}\text { Degradation produces hydrogen } \\
\text { Complex manufacturing process }\end{array}$ \\
\hline \multirow{3}{*}{ Bioceramics } & Hydroxyapatite & $\begin{array}{l}\text { Chemical composition is the same } \\
\text { as the bone tissue } \\
\text { Conducive to cell adhesion and } \\
\text { proliferation, promotes } \\
\text { biomineralization } \\
\text { Excellent osteogenesis and } \\
\text { osseointegration }\end{array}$ & $\begin{array}{l}\text { Slow degradation rates and poor } \\
\text { biomechanical properties impede } \\
\text { complete bone formation and increase } \\
\text { the risk of fracture } \\
\text { Relatively weak bone conduction } \\
\text { capacity }\end{array}$ \\
\hline & $\begin{array}{l}\text { Tricalcium } \\
\text { phosphate }\end{array}$ & $\begin{array}{l}\text { Excellent bioactivity, } \\
\text { biocompatibility, and absorbability } \\
\text { A strong bone calcium phosphate } \\
\text { bond can be formed to stabilize the } \\
\text { scaffold and the host bone }\end{array}$ & \multirow{2}{*}{$\begin{array}{l}\text { The rate of degradation did not match } \\
\text { the rate of new bone formation } \\
\text { Cannot be used as a load-bearing area } \\
\text { implant } \\
\text { High solubility and faster degradation } \\
\text { rates increase ambient } \mathrm{pH} \text { and affect } \\
\text { osseointegration }\end{array}$} \\
\hline & Silicate ceramic & $\begin{array}{l}\text { Simple manufacturing process } \\
\text { Excellent compressive strength } \\
\text { Good mineralization ability to } \\
\text { promote fracture healing }\end{array}$ & \\
\hline
\end{tabular}


Bioactive composites for bone regeneration

\begin{tabular}{|c|c|c|c|}
\hline Materials & $\begin{array}{l}\text { Detailed } \\
\text { classification }\end{array}$ & Advantages & Potential limitations \\
\hline & Silicate bioglass & $\begin{array}{l}\text { Promotes bone regeneration and } \\
\text { blood vessel formation } \\
\text { Excellent bone conduction and } \\
\text { bone regeneration ability } \\
\text { Resistance to twisting and bending }\end{array}$ & $\begin{array}{l}\text { Rate of degradation does not match } \\
\text { the rate of bone regeneration } \\
\text { Higher hardness results in stress } \\
\text { concentration and hinders the } \\
\text { matching between the implant and the } \\
\text { host bone }\end{array}$ \\
\hline & $\begin{array}{l}\text { Phosphate } \\
\text { Bioglass }\end{array}$ & $\begin{array}{l}\text { Excellent compressive strength } \\
\text { Suitable for drug delivery }\end{array}$ & $\begin{array}{l}\text { Texture is crisp } \\
\text { May have toxic substances }\end{array}$ \\
\hline & Borate bioglass & $\begin{array}{l}\text { Earlier mineralization capacity } \\
\text { Good osteoinductivity }\end{array}$ & $\begin{array}{l}\text { Breaking strength is low } \\
\text { Rate of degradation is difficult to } \\
\text { control }\end{array}$ \\
\hline \multirow{8}{*}{ Polymers } & Alginate & $\begin{array}{l}\text { Wide variety of sources } \\
\text { Can be hydrogel scaffold } \\
\text { Low immunogenicity }\end{array}$ & $\begin{array}{l}\text { May contain toxins } \\
\text { Lack of tissue specificity } \\
\text { Not conducive to cell adhesion }\end{array}$ \\
\hline & Agarose & $\begin{array}{l}\text { Promotes osteoblast growth } \\
\text { Promotes matrix deposition }\end{array}$ & $\begin{array}{l}\text { Lack of mineralization capacity } \\
\text { Low modulus of elasticity }\end{array}$ \\
\hline & Chitosan & $\begin{array}{l}\text { Rich source } \\
\text { Good biocompatibility } \\
\text { Has certain antibacterial properties }\end{array}$ & $\begin{array}{l}\text { High shrinkage capacity, high } \\
\text { degradation rate } \\
\text { Lower mechanical strength }\end{array}$ \\
\hline & Hyaluronic acid & $\begin{array}{l}\text { Excellent biocompatibility } \\
\text { Low-cost availability }\end{array}$ & $\begin{array}{l}\text { Differences in finished products } \\
\text { manufactured in the same batch may } \\
\text { be large } \\
\text { Produces a rapidly degrading area } \\
\text { accompanied by the release of acidic } \\
\text { factors }\end{array}$ \\
\hline & Collagen & $\begin{array}{l}\text { Excellent biocompatibility, } \\
\text { supporting osteoblast adhesion, and } \\
\text { differentiation } \\
\text { Good biodegradability, no acid } \\
\text { degradation products }\end{array}$ & $\begin{array}{l}\text { Poor mechanical properties } \\
\text { Poor osteoconductive }\end{array}$ \\
\hline & PCL & $\begin{array}{l}\text { Low cost } \\
\text { Degradable by hydrolysis } \\
\text { Thermal stability } \\
\text { Suitable mechanical properties }\end{array}$ & $\begin{array}{l}\text { Degradation products reduce the } \\
\text { surrounding } \mathrm{pH} \\
\text { Poor osteoinductive }\end{array}$ \\
\hline & PLGA & $\begin{array}{l}\text { Good security } \\
\text { Good cell adhesion } \\
\text { Ideal mechanical properties and } \\
\text { controlled degradation rate }\end{array}$ & $\begin{array}{l}\text { Poor biological activity } \\
\text { Unable to provide good } \\
\text { osseointegration }\end{array}$ \\
\hline & PLA & $\begin{array}{l}\text { Produced from renewable resources } \\
\text { Biodegradable }\end{array}$ & $\begin{array}{l}\text { Degradation products may cause } \\
\text { inflammatory reactions }\end{array}$ \\
\hline \multirow{2}{*}{ Composites } & Metal-ceramic & $\begin{array}{l}\text { Controllable components } \\
\text { Customizable material properties } \\
\text { Suppress the disadvantages of the } \\
\text { constituent raw materials }\end{array}$ & Complicated production process \\
\hline & Polymer-ceramic & $\begin{array}{l}\text { Adjustable biological and } \\
\text { mechanical properties } \\
\text { Magnifies the advantages of the raw } \\
\text { materials }\end{array}$ & $\begin{array}{l}\text { Best composition ratio requires } \\
\text { further study } \\
\text { High cost }\end{array}$ \\
\hline
\end{tabular}

\section{Materials used for bioactive composites}

Biomaterials utilized in bone tissue osteoconductive, or osseointegration properties. engineering should provide osteoinductive, Growth factors and stem cells are needed for 
osteoinductivity, allowing commitment of mesenchymal stem cells (MSCs) to differentiate into osteoblasts. Osteoconductive scaffolds are those that give appropriate functional bone formation on their surfaces. Osseointegration is the phenomenon observed in the margin of the scaffolds and the surrounding bone tissue when the bone tissue begins penetrating the scaffolds through the boundary [8].

\subsection{Cements}

Because of the importance of self-setting property, cement has been used clinically for many years. Essentially, industrial cements were also used in dental and medical domains. As a result, the history of bioactive cement is close to the history of industrial cement. In other words, calcium sulfate or plaster has the oldest history as bioactive cement even though its bioactivity is restricted. Portland cement is also used as a medical cement for the restoration of the bone. Interestingly, its utilization as mineral trioxide aggregate (MTA) for dental treatment is one of the key topics in dentistry [9]. Biocompatible cements for orthopedic surgery are acrylic cements, which are principally used in the fixation of joint prostheses to the bone, and ceramic cements that are used to fill osseous defects. The latter class is composed mainly of calcium phosphate and calcium sulfate cements [4]. Apparently, advantages of bioactive cements emerged from their self-setting property at physiological temperature or low temperature. First, the paste can set and harden, for example, at the bone defect. Therefore, the bone defect can be filled with the cement without leaving a gap between the surrounding bone and cement. In other words, the surrounding bone and set cement have continuity between them [9].

A few scientists built up a quick-setting calcium silicate bone cement with high bioactivity and improved osteogenesis after mixing with phosphate solution. Therefore, calcium silicate bone cement opened up new opportunities in the domain of self-setting bioactive $\mathrm{CaO}-\mathrm{SiO}_{2}$-based bone filling and bone graft. Tricalcium silicate, which has drawn growing attention, is a promising biomaterial; in reent studies, the potential of tricalcium silicate cement as an injectable bone substitute has been analyzed, and the results indicate that $\mathrm{Ca}_{3} \mathrm{SiO}_{5}$ pastes provide good bioactivity and injectability, and a moderate in vitro biodegradability. Tricalcium silicate is the principal unit of Portland cement, and can react with an aqueous phase at room or body temperature to form an injectable cement paste [10].

Most of the injectable calcium phosphates utilized evolve to an apatitic calcium phosphate during the setting reaction. The physicochemical properties of these materials, such as the porosity, setting time, and mechanical behavior, rely upon the cement formulation and the presence of additives. These cements cure at the site, are biocompatible and can be resorbed slowly. During this gradual process, the newly formed bone grows and replaces the cement. Some characteristics that must be enhanced are related to their mechanical toughness, the curing time, the application technique on the osseous defect, and the final biological properties [11].

\subsection{Glass-ceramics}

The main bioactive ceramic material designed was the Bioglass, which was composed of 45 wt. $\%$ $\mathrm{SiO}_{2}, 24.5$ wt. $\% \quad \mathrm{Na}_{2} \mathrm{O}, 24.5$ wt. $\% \mathrm{CaO}$, and 6 wt. $\% \mathrm{P}_{2} \mathrm{O}_{5}$, and therefore named 45S5. Bioglass history began in 1969 when Professor Larry Hench acknowledged the huge costs regarding the treatment of wounds from amputations during the Vietnam War [12].

The main disadvantage of bioactive glasses is their low mechanical strength. Porous glass scaffolds are brittle and have poor fracture toughness, which thereby precludes their use in load-bearing applications. While a high degree of crystallization decreases the bioactivity of some composition, partial crystallization can lead to instability, as the residual amorphous regions undergo preferential dissolution. Despite their disadvantages, glass-ceramics are considerately suitable for bone tissue engineering due to their dense and finely graded microstructure. To overcome the disadvantages, mainly related to the low mechanical strength of porous scaffolds, numerous strategies have been explored including composites of glass or glass-ceramic, compositional modification, natural-derived or synthetic polymers, and scaffolds developed with oriented microstructures, anisotropic mechanical properties, and tailored porosity [13].

Due to its property to bond with bone tissues, bioglass has been used to fill bone fractures and bone tissue degenerations. While bone fracture is produced by accidents like a car crash, accidents in 
the home or at the workplace, bone tissue degeneration can be caused by various factors that lead to bone demineralization and modifications in the structure and reduction of collagen. These factors can be an abnormal function of the mineral metabolism (calcium, magnesium, and phosphorus) and because of a hormonal imbalance, genetic problems, and other mechanisms associated with human cell biology. Bioglass can be utilized to regress these conditions and to recover the bone function through its regenerations, which take place via gene activation. This gene activation, in turn, occurs because the ions released from the glass during glass dissolution can connect with cells around the implant site, and then act as cell signaling through an ionic pathway. Therefore, bioglass permits the bone tissue to have its biofunctionality back [14].

\subsection{Polymers}

The utilization of biocompatible synthetic materials such as calcium phosphates or biodegradable polymers in the case of bone has gained importance in the last decades. Their synthetic nature avoids rejections and unfavorable biological responses apart from decreasing the limitations and high cost generally associated with biological strategies such as growth factor therapies or allografts/xenografts. However, their bioactive potential is often lower than these biological strategies precisely due to their nonbiological origin [15].

Ceramic/polymer composites have been used as bone tissue engineering scaffolds due to their mixed advantages of improved biologic, physicochemical, and mechanical properties, and in particular the efficiency they provide in tailoring their structure and degradation rate to the specific need at the implant site. Typical examples of these composites are described by numerous authors. Overall, as engineering technology continues to evolve, future synthetic scaffolds can only be expected to perform better [16]. As an emerging technology, 3D bioprinting provides a potential solution to help ease the burden of arthritis and other causes of bone defects within orthopedics. Bioprinting can be used to deposit extracellular matrices, living cells, and other biomaterials in user-defined patterns to build advanced tissue constructs 'from the bottom up'. The process of bioprinting normally begins with the selection of cells and biomaterials for inclusion in bioprinted constructs (Figure 1) [1].

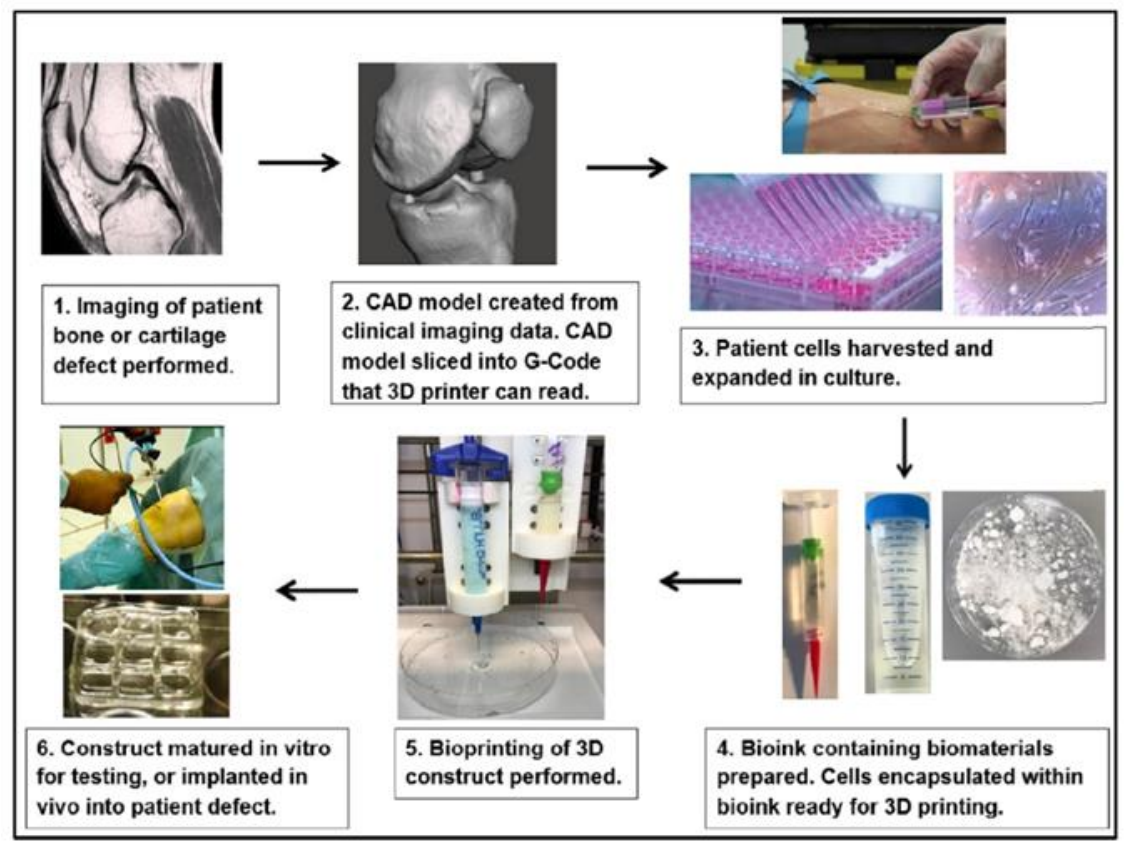

Figure 1. Summary of bioprinting process [1]. Reprinted from an open access source.

The most often used biodegradable synthetic polymers for $3 \mathrm{D}$ scaffolds in tissue engineering are the family of poly $(\alpha$-hydroxyester $) \mathrm{s}$ and copolyesters of lactic acid and glycolic acid. Members of this ester-backbone polymer group are poly(glycolic acid) (PGA), and poly(lactic acid) (PLA, PLLA), as well as poly(lactic-co-glycolide) (PLGA) copolymers and poly(caprolactone) (PCL) [16]. Recently, it has been demonstrated that pseudowollastonite ( $\mathrm{psW}$ ), as a silica-based 
polycrystalline ceramic ( $\alpha-\mathrm{CaSiO} 3)$, mixed with poly(L,L-lactide), as a bioresorbable polymer, can lead to an improved bioactive composite for osseointegration [17]. Numerous natural polymers have in their composition specific molecular domains that could promote the differentiation and proliferation of chondrocytes. However, in comparison with other materials, natural polymers possess low stiffness and weak biomechanical properties [18]. Among the many polysaccharides, polymeric carbohydrate molecules composed of long chains of monosaccharide units bound together by glycosidic bonds, like chitosan, chitin,

\section{Conclusions}

The appearance of bioactive cements is one of the biggest successes for biomaterials aimed for the reconstruction of bone defects. Although newly developed bioactive cements provide many benefits to patients, the area needs to be thoroughly studied. Future studies should be done according to the full understanding of the clinical needs and findings from previous studies. Apatite cements also have a lot of properties to be enhanced. One of them may be to boost the mechanical strength for wider clinical applications. Some increase could be possible by introducing the already established calcium sulfate technology. Also, a further increase could be realized by introducing the already established Portland cement technology.

Bioactive glass-ceramics represent an inspiring and prospective class of functional biomaterials. Their elegance resonates with the central of materials science, i.e., to add comfort to livelihood with a possible extension of human life. The main advantage of glass-ceramics for bone tissue

\section{Funding}

This research received no external funding.

\section{Conflicts of Interest}

The authors declare no conflict of interest.

\section{Acknowledgments}

The authors declare no acknowledgments.

\section{References}

1. Turnbull, G.; Clarke, J.; Picard, F.; Riches, P.; Jia, L.; Han, F.; Li, B.; Shu, W. 3D bioactive composite scaffolds for bone tissue engineering. hyaluronic acid, alginates, etc., possess desirable properties. It has been reported that scaffolds synthesized of chitin-bioglass by lyophilization technique demonstrate adequate swelling and degradation as well as enhanced bioactivity, revealed by the increased deposition of apatite on the surface of the composite [19]. Polymer nanocomposites normally provide new possibilities as materials for bone tissue regeneration because the sizes of the nanoparticles are identical to those of bone components and they may connect at the nano-level [20].

engineering is represented by the dense and finely graded microstructure. Bioglass can be used to fill bone fractures and bone tissue degenerations due to its property to bond with bone tissues.

In the past 20 years, numerous combinations of biopolymers and inorganic fillers were designed in the form of tissue engineering scaffolds for biomedical applications. Bioglass, besides improving the polymeric implant biological performance, due to its high specific surface-areato-volume ratio that contributes to the scaffold superior protein and cell adhesion, can also raise its alkalinity, which can protect at the great extent the acidic degradation of some polymers. The possibility of adding growth factors into composites formed with the aim to accelerate local vascularization and bone healing is promising and has begun to be explored. Inducing rapid vascular ingrowth during tissue development is of major importance in tissue engineering and it needs to be studied closely. 
2. Johannesdottir, F.; Bouxsein, M.L. Chapter 12 Overview of Bone Structure and Strength. In: Genetics of Bone Biology and Skeletal Disease, Thakker, R.V., Whyte, M.P., Eisman, J.A., Igarashi, T.; editors. (Second Edition): Academic Press; 2018; pp. 197-208, https://doi.org/10.1016/B978-0-12-804182-6.00012-5.

3. O'Brien, F.J. Biomaterials \& scaffolds for tissue engineering. Materials Today. 2011, 14, 88-95, https://doi.org/10.1016/S1369-7021(11)70058-X.

4. Baino, F. Chapter 7-Ceramics for bone replacement: Commercial products and clinical use, In: Advances in Ceramic Biomaterials, Palmero, P., Cambier, F., De Barra, E., editors. Woodhead Publishing; 2017; pp. 249-78, https://doi.org/10.1016/B978-0-08-100881-2.00007-5.

5. Vallet-Regí, M.; Salinas, A.J. Chapter 6-Ceramics as bone repair materials, In: Bone Repair Biomaterials, Pawelec, K.M., Planell, J.A., editors. (Second Edition): Woodhead Publishing; 2019; pp. 141-78, https://doi.org/10.1533/9781845696610.2.194.

6. Bai, X.; Gao, M.; Syed, S.; Zhuang, J.; Xu, X.; Zhang, X.Q. Bioactive hydrogels for bone regeneration. Bioact Mater. 2018, 3, 401-17, https://doi.org/10.1016/j.bioactmat.2018.05.006.

7. Leng, Y.; Yang, F.; Wang, Q.; Li, Z.; Yuan, B.; Peng, C. ; Ren, G.; Wang, Z.; Cui, Y.; Wang, Y.; Zhu, L.; Wu, D. Material-based therapy for bone nonunion. Materials \& Design 2019, 183, 108161, https://doi.org/10.1016/j.matdes.2019.108161.

8. Rao, S.H.; Harini, B.; Shadamarshan, R.P.K.; Balagangadharan, K.; Selvamurugan, N. Natural and synthetic polymers/bioceramics/bioactive compoundsmediated cell signalling in bone tissue engineering. International journal of biological macromolecules 2018, 110, 8896, https://doi.org/10.1016/i.ijbiomac.2017.09.029.

9. Ishikawa, K. Chapter 1.17 Bioactive Ceramics: Cements. In: Comprehensive Biomaterials II. Ducheyne, P., editor. Oxford: Elsevier; 2017; pp. 368-91, http://dx.doi.org/10.1016/B978-0-08-055294-1.000295.

10. Zhang, Y.; Wu, Z.; Shu, Y.; Wang, F.; Cao, W.; Li, W. A novel bioactive vaterite-containing tricalcium silicate bone cement by self hydration synthesis and its biological properties. Materials science \& engineering $C$ 2017, 79, 23-9, https://doi.org/10.1016/j.msec.2017.05.025.

11. Bouler, J.M.; Pilet, P.; Gauthier, O.; Verron, E. Biphasic calcium phosphate ceramics for bone reconstruction: A review of biological response. Acta Biomaterialia 2017, 53, 1-12, https://doi.org/10.1016/j.actbio.2017.01.076.

12. Mesquita-Guimarães, J.; Henriques, B.; Silva, F.S.; Souza, J.C.M.; Novaes de Oliveira, A.P.; Hotza, D.; do
Nascimento, R.M.; Fredel. M.C. Chapter 6Nanostructured biocompatible ceramics and glassceramics. In: Nanostructured Biomaterials for CranioMaxillofacial and Oral Applications Souza, J.C.M., Hotza, D., Henriques, B., Boccaccini, A.R., editors.: Elsevier; 2018; pp. 97-118, https://doi.org/10.1016/B978-0-12814621-7.00006-8.

13. Shah, F.A.; Czechowska, J. Chapter 9 - Bioactive glass and glass-ceramic scaffolds for bone tissue engineering. In: Bioactive Glasses, (Second Edition), Ylänen, H., editor. Woodhead Publishing; 2018; pp. 201-33, https://doi.org/10.1016/B978-0-08-1009369.00011-3.

14. Zambanini, T.; Borges, R.; Kai, K.C.; Marchi, J. Chapter 14 - Bioactive Glasses for Treatment of Bone Infections, In: Biomedical, Therapeutic and Clinical Applications of Bioactive Glasses, Kaur, G. editor; Woodhead Publishing; 2019; pp. 383-415, https://doi.org/10.1016/B978-0-08-102196-5.00014-8.

15. Martí-Muñoz, J.; Castaño, O. Chapter 11-Bioactive fibers for bone regeneration. In: Electrofluidodynamic Technologies (EFDTs) for Biomaterials and Medical Devices, Guarino, V., Ambrosio, L. editors, Woodhead Publishing; 2018; pp. 205-20, https://doi.org/10.1016/B978-0-08-101745-6.00011-6. 16. Alvarez-Urena, P.; Kim, J.; Bhattacharyya, S.; Ducheyne, P. Chapter 6.1-Bioactive Ceramics and Bioactive Ceramic Composite Based Scaffolds, In: Comprehensive Biomaterials II. Ducheyne, P. editor. Oxford: Elsevier; 2017; pp. 1-19, http://dx.doi.org/10.1016/B978-0-12-803581-8.101365.

17. Barone, D.; Raquez, J.M.; Dubois, P. Bone-guided regeneration: From inert biomaterials to bioactive polymer (nano)composites. Polymers for Advanced Technologies 2011, 22, 463-75, https://doi.org/10.1002/pat.1845.

18. Deng, C.; Chang, J.; Wu, C. Bioactive scaffolds for osteochondral regeneration. Journal of Orthopaedic Translation 2019, 17, 15-25, https://doi.org/10.1016/i.jot.2018.11.006.

19. Felgueiras, H.P.; Amorim, M.T.P. Chapter 12Production of polymer-bioactive glass nanocomposites for bone repair and substitution. In: Materials for Biomedical Engineering, Elsevier; Holban, A.M., Grumezescu, A.M., editors. 2019; pp. 373-96, https://doi.org/10.1016/B978-0-12-816909-4.00012-9.

20. Pielichowska, K.; Blazewicz, S. Bioactive Polymer/Hydroxyapatite (Nano) Composites for Bone Tissue Regeneration. Biopolymers 2010, 232, pp. 97-207, https://doi.org/10.1007/12_2010 50. 